\title{
Evaluation of Salinity Stress on Marigold's Growth with Bacteria Inoculation
}

\author{
Abedini Tina*1, Moradi Pezhman ${ }^{2}$, Zeinab Deris ${ }^{3}$ \\ ${ }^{1}$ Horticultural Department, Islamic Azad University, Karaj Branch, Karaj, Iran \\ ${ }^{2}$ Horticultural Department, Islamic Azad University, Saveh Branch, Saveh, Iran \\ ${ }^{3}$ Agronomy Department, Razi University, Kermanshah, Iran
}

\begin{abstract}
This study was performed to Evaluation of salinity stress on marigold's growth with Bacteria inoculation with afactorial experimental design and 3 replications. First factor was bacteria (inoculated and no inoculated) and second factor was salinity stress (control, 2, 4 and $8 d S / m$ ). After the experiment, some morphological characters and morphological of marigold were evaluated such as height, yield of fresh and dried flowers, number of flowers per plant, grain yield, petals, seed weight. Totally, it was founded that with increased stress levels from 0 to $8 d S$, the height, fresh yield of flowers, yield of flower dry weight, number of flowers per plant, grain yield, petals and seed weight, showed 43, 60, 56, 17, 64, 15 and 30percent of reduction, respectively. Also, it was determined that the using of bacteria can reduce the effects of stress on marigold.
\end{abstract}

Keywords-Bacteria, Marigold, Stress.

\section{INTRODUCTION}

Pot marigold (Calendula officinalis L.) is from Asteraceae family,this plant has medicinal properties and it is used for treatment of skin diseases (rafeeet al., 2013). Salinity is a soil condition by high content of soluble salts. The problem of soil salinity is increasing. Soil salinity stresses plants in two ways: High concentrations of salts in the soil make it harder for roots to extract water, and high concentrations of salts within the plant can be toxic (Munns and Tester, 2008). Adverse effects of salinity on plant growth may be due to ion cytotoxicity and osmotic stress (Hussain et al, 2008). Metabolic imbalances caused by ion toxicity, osmotic stress and nutritional deficiency under saline conditions may also lead to oxidative stress (Zhu, 2002). Also, Application of bio fertilizers in conventional farming systems is not common and most of the nutritional need of plants supply through chemical fertilizers for short period. Excessive and unbalanced use of fertilizers in the long period, reduce crop yield and soil biological activity, accumulation of nitrates and heavy metals, and finally cause negative environmental effects and increase the cost of production. The use of biofertilizers and organic matter are taken into consideration to reduce the use of chemical fertilizers and increase the quality of most crops.Plant growth promotingrhizobacteriaare a group of bacteria that activelycolonize plant roots and increase plant growthand yield. The action mechanisms of PGPRs canbe dividedinto direct and indirect ones.Directmechanisms include $\mathrm{N}_{2}$ fixation, soil mineralsolubilization, and productionofplant growth promoting substances (auxins, cytokinins orgibberellins) and reduction of ethylene levels, amongothers. Indirect mechanisms include favoring colonization by other beneficial soilmicroorganisms, such as mycorrhizal fungi, andrepressing the growth of plant pathogenicmicroorganisms(Lugtenberg et al,. 2009; Marulandaet al., 2010; Gholamiet al, 2009).In this order, the aim of study was Evaluation of salinity stress on marigold's growth with Bacteria inoculation.

\section{MATERIAL AND METHODS}

Experimental design performed asfactorial design with 3 replications. First factor was bacteria (inoculated and no inoculated) and second factor was salinity stress (control, 2 , 4 and $8 \mathrm{dS} / \mathrm{m}$ ). After the experiment, some morphological characters and morphological of marigold were evaluated such as height, yield of fresh and dried flowers, number of flowers per plant, grain yield, petals, seed weight.In order to analyze of data SAS software was used and mean comparisons were performed by using Duncan's multilateral.

\section{RESULT AND DISCUSSION}

Height: Table1 shows result of analysis of variance on height. Incubated bacteria had significant on height, this result shown at table 2. The comparison of mean with Duncan test showed that the treatments of 2, 4and $8 \mathrm{dS} / \mathrm{m}$ 
resulted decreasing in 5 , 5and 1 percent in comparison to the control. According to interaction between incubation with salinity, it was founded that incubation led to reduction of salinity negative effects on height (Table 2). Kumar et al (2012) mentioned that Lower salinity $\left(3 \mathrm{dsm}^{-1}\right)$ did not affect the germination, growth and yield attributing parameters. Higher salinity levels reduced germination, growth and yield attributing parameters

Yield of fresh flowers:Incubated bacteria had significant on yield of fresh flowers,so that,this trait increased $29 \%$ by application of incubated bacteria. The comparison of mean with Duncan test showed that the treatments of 2, 4and $8 \mathrm{dS} / \mathrm{m}$ resulted decreasing in 2,17 and 52 percent in comparison to the control. According to interaction between incubation with salinity, it was founded that incubation led to reduction of salinity negative effects on yield of fresh flowers (Table 2).

Yield of dry flowers: Incubated bacteria had significant on yield of dry flowers, so that, this trait increased $50 \%$ by application of incubated bacteria. The comparison of mean with Duncan test showed that the treatments of 2, 4and $8 \mathrm{dS} / \mathrm{m}$ resulted decreasing in 2, 36 and 53 percent in comparison to the control.According to interaction between incubation with salinity, it was founded that incubation led to reduction of salinity negative effects on yield of dry flowers (Table 3).

Number of flowers per plant:Number of flowers per plant was affected by all factors.Incubated bacteria had significant on yield of dry flowers, so that, this trait increased $42 \%$ by application of incubated bacteria. Applied salinity caused a significant reduction in Number of flowers per plant; the treatments of 2 , 4and $8 \mathrm{dS} / \mathrm{m}$ resulted decreasing in 2, 4 and 12 percent as compared to the control.According to interaction between incubation with salinity, it was founded that incubation led to reduction of salinity negative effects on number of flowers per plant (Table 2).Salt tension can affect plant survival, plant height, biomass and plant morphology as well as the ability of a plant to gather water and nutrients (Parida and Das, 2005). The huge effect of salinity is deficiency in hormones (Jaleel et al., 2007).

Grain yield:This characteristic was affected by simple effects and interaction effect of treatments, it was founded that using of bacteria increased grain yield about $52 \%$ but, salinity stress led to reduction of grain yield, so that, application of 2, 4 and $8 \mathrm{dS} / \mathrm{m}$ resulted decreasing in 11,46 and 70 percent as compared to the control. According to interaction between incubation with salinity, it was founded that incubation led to reduction of salinity negative effects on grain yield (Table 2). The decrease in grain yield might be caused by the salinity, which induced reduction of photosynthetic capacity leading to less starch synthesis and accumulation in the grain (Turki et al., 2012).

Petals yield:Table1 shows result of analysis of variance on petals yield. According to means comparison, Incubated bacteria had significant on height, this result shown at table 2. The comparison of mean with Duncan test showed that the treatments of 2,4 and $8 \mathrm{dS} / \mathrm{m}$ resulted decreasing in 4,6 and 8 percent in comparison to the control.According to interaction between incubation with salinity, it was founded that incubation led to reduction of salinity negative effects on petals yield (Table 2).

1000Seed weight: 1000 Seed weight was affected by all factors (Table 1). In relation to incubated bacteria had significant on yield of dry flowers, so that, this trait increased 2 fold by application of incubated bacteria. Applied salinity caused a significant reduction in number of flowers per plant; the treatments of 2 , 4 and $8 \mathrm{dS} / \mathrm{m}$ resulted decreasing in 4, 17 and 18 percent as compared to the control.According to interaction between incubation with salinity, Salinity is of concern because of its deleterious effect on plant growth, nutritional balance, and plant and flower marketable quality, including visual injury, flower distortion, and reduced stem length. Plant growth is detrimentally affected by salinity as a result of the disruption of certain physiological processes that lead to reductions in yield and/or quality. Growth, yield, and quality reduction may occur through a decrease in the ability of plants to take up water from the soil solution and the destruction of soil structure (Barrett-Lennard, 2003). In addition,toxicity resulting from excessive concentration of certain ions, principally $\mathrm{Na}^{+}, \mathrm{Ca}^{2+}, \mathrm{Mg}^{2+}, \mathrm{Cl}^{-}, \mathrm{SO}^{2-}$ and $\mathrm{HCO}_{3}{ }^{-}$as well as nutritional imbalances (Grattan and Grieve 1999), may also play important roles in the response of plants in saline environments.

\section{CONCLUSION}

Totally, result showed that $\mathrm{t}$ with increasing stress levels from control to $8 \mathrm{dS} / \mathrm{m}$, the height, fresh yield of flowers, yield of flower dry weight, number of flowers per plant, grain yield, petals and seed weight, showed 43, 60, 56, 17, 64, 15 and 30 percent of reduction, respectively. On the other hand, it was determined that the using of bacteria can reduce the effects of stress. 
Table.1: analysis of variance of studied traits

\begin{tabular}{|l|l|l|l|l|l|l|l|l|}
\hline Anova & d.f & Height & $\begin{array}{l}\text { Yield of } \\
\text { fresh } \\
\text { flowers }\end{array}$ & $\begin{array}{l}\text { Yield of } \\
\text { dried } \\
\text { flowers }\end{array}$ & $\begin{array}{l}\text { Number of } \\
\text { flowers per } \\
\text { plant }\end{array}$ & $\begin{array}{l}\text { Grain } \\
\text { yield }\end{array}$ & $\begin{array}{l}\text { Petals } \\
\text { yield }\end{array}$ & $\begin{array}{l}\text { Seed } \\
\text { weight }\end{array}$ \\
\hline Replication & 2 & 7.43 & 50.2 .0 & $12.6^{*}$ & 2.1 & 3.4 & $45.8^{* *}$ & 4.98 \\
\hline Bacteria & 1 & $143.2^{* *}$ & $178.2^{* *}$ & $65.0^{* *}$ & $20.8^{* *}$ & $25.3^{* *}$ & $11.6^{* *}$ & $45.6^{* *}$ \\
\hline Stress & 3 & $122.1^{* *}$ & $319.5^{* *}$ & $110.8^{* *}$ & $34.7^{* *}$ & $71.9^{* *}$ & $14.9^{* *}$ & $69.7^{* *}$ \\
\hline Bacteria*stress & 3 & $23.0^{*}$ & $165.3^{* *}$ & $17.4^{* *}$ & $4.9^{*}$ & $14.3^{* *}$ & $8.8^{*}$ & $11.2^{*}$ \\
\hline Error & 14 & 5.4 & 44.3 & 3.6 & 1.1 & 2.1 & 2.1 & 3.2 \\
\hline
\end{tabular}

Table.2: Means comparison between treatments effects on studied traits (Duncan 5\%)

\begin{tabular}{|c|c|c|c|c|c|c|c|c|c|c|c|c|c|c|c|c|}
\hline \multirow[b]{2}{*}{$\begin{array}{c}\text { no } \\
\text { inoculation }\end{array}$} & \multirow{2}{*}{$\begin{array}{c}\text { Salinity } \\
(\mathrm{dS} / \mathrm{m})\end{array}$} & \multirow{2}{*}{$\begin{array}{c}\text { Height } \\
(\mathrm{cm})\end{array}$} & \multirow[b]{2}{*}{$\mathrm{c}$} & \multicolumn{2}{|c|}{$\begin{array}{l}\text { Yield of } \\
\text { fresh } \\
\text { flowers } \\
\text { (gr/plant) }\end{array}$} & \multicolumn{2}{|c|}{$\begin{array}{l}\text { Yield of } \\
\text { dry } \\
\text { flowers } \\
\text { (gr/plant) }\end{array}$} & \multicolumn{2}{|c|}{$\begin{array}{c}\text { Number of } \\
\text { flowers per } \\
\text { plant }\end{array}$} & \multicolumn{2}{|c|}{$\begin{array}{c}\text { Grain yield } \\
\text { (gr/plant) }\end{array}$} & \multicolumn{2}{|c|}{$\begin{array}{l}\text { Petals yield } \\
\text { (mg/ flower) }\end{array}$} & \multicolumn{3}{|c|}{$\begin{array}{c}\text { 1000seed weight } \\
\text { (gr) }\end{array}$} \\
\hline & & & & 15.5 & $\mathrm{~d}$ & 3.90 & b & 3.0 & $\mathrm{~b}$ & 10.0 & c & 32.5 & $\mathrm{~d}$ & 8.83 & $d$ & \\
\hline & 2 & 32 & $\mathrm{c}$ & 15.8 & $\mathrm{~d}$ & 3.99 & $\mathrm{~b}$ & 3.0 & $\mathrm{~b}$ & 10.5 & $\mathrm{c}$ & 31.0 & $\mathrm{e}$ & 8.83 & $\mathrm{~d}$ & \\
\hline & 4 & 31 & $\overline{c d}$ & 15.9 & $\mathrm{~d}$ & 3.97 & $\mathrm{~b}$ & 2.9 & $\mathrm{~b}$ & 10.0 & $\mathrm{c}$ & 30.0 & ef & 6.833 & $\mathrm{e}$ & \\
\hline & 8 & 29 & $\mathrm{~d}$ & 7.5 & $\mathrm{e}$ & 1.90 & $\mathrm{~d}$ & 2.8 & $\mathrm{~b}$ & 2.0 & $\mathrm{e}$ & 29.5 & $\mathrm{f}$ & 5.5 & $\mathrm{f}$ & \\
\hline inoculation & 0 & 39.5 & $\mathrm{a}$ & 18.0 & $\mathrm{a}$ & 5.58 & $\mathrm{a}$ & 4.4 & a & 13.5 & $\mathrm{a}$ & 38.5 & $\mathrm{a}$ & 14.5 & $\mathrm{a}$ & \\
\hline & 2 & 36.5 & $\mathrm{~b}$ & 17.3 & $a b$ & 5.35 & $\mathrm{a}$ & 4.4 & $\mathrm{a}$ & 12.9 & $a b$ & 37.0 & $a b$ & 13.5 & $\mathrm{~b}$ & \\
\hline & 4 & 34.5 & $\mathrm{~b}$ & 16.8 & $\mathrm{~cd}$ & 5.20 & $\mathrm{a}$ & 4.3 & $\mathrm{a}$ & 12.4 & $\mathrm{~b}$ & 36.5 & $\mathrm{bc}$ & 12.5 & $\mathrm{c}$ & \\
\hline & 8 & 35.5 & $\mathrm{~b}$ & 8.3 & $\mathrm{e}$ & 2.57 & $\mathrm{c}$ & 3.7 & $a b$ & 3.9 & $\mathrm{~d}$ & 35.5 & $\mathrm{c}$ & 13.5 & $\mathrm{~b}$ & \\
\hline
\end{tabular}

At each column, means with similar alphabet don't show significant differences.

\section{REFERENCES}

[1] Barrett-Lennard, E.G., 2003. The interaction between waterlogging and salinity in higher plants: causes, consequences and implications. Plant and Soil, 253(1), pp.35-54.

[2] Gholami, A., Shahsavani, S. and Nezarat, S., 2009. The effect of plant growth promoting rhizobacteria (PGPR) on germination, seedling growth and yield of maize. Int J Biol Life Sci, 1(1), pp.35-40.

[3] Grattan, S.R. and Grieve, C.M., 1998. Salinitymineral nutrient relations in horticultural crops. ScientiaHorticulturae, 78(1), pp.127-157.

[4] Hussain, T.M., Hazara, M., Sultan, Z., Saleh, B.K. and Gopal, G.R., 2008. Recent advances in salt stress biology a review. Biotechnology and Molecular Biology Reviews, 3(1), pp.8-13.

[5] Jaleel, C.A., Gopi, R., Manivannan, P. and Panneerselvam, R., 2007. Responses of antioxidant defense system of Catharanthusroseus (L.) G. Don. topaclobutrazol treatment under salinity. ActaPhysiologiaePlantarum, 29(3), pp.205-209.

[6] Kumar, R.A.J.E.E.V., Singh, M.P. and Kumar, S., 2012. Effect of salinity on germination, growth, yield and yield attributes of wheat. International Journal of Scientific \& Technology Research, 1, pp.19-23.

[7] Lugtenberg, B. and Kamilova, F., 2009. Plant-growthpromoting rhizobacteria. Annual review of microbiology, 63, pp.541-556.

[8] Marulanda, A., Azcón, R., Chaumont, F., RuizLozano, J.M. and Aroca, R., 2010. Regulation of plasma membrane aquaporins by inoculation with a Bacillus megaterium strain in maize (Zea mays L.) plants under unstressed and salt-stressed conditions. Planta, 232(2), pp.533-543.

[9] Munns, R. and Tester, M., 2008. Mechanisms of salinity tolerance. Annu. Rev. Plant Biol., 59, pp.651681. 
[10] Parida, A.K. and Das, A.B., 2005. Salt tolerance and salinity effects on plants: a review. Ecotoxicology and environmental safety, 60(3), pp.324-349.

[11] Rafiee, H., Mehrafarin, A., Qaderi, A., KalateJari, S. and NaghdiBadi, H., 2013. Phytochemical, agronomical and morphological responses of pot marigold (Calendula officinalis L.) to foliar application of bio-stimulators (bioactive amino acid compounds). Journal of Medicinal Plants, 3(47), pp.48-61.

[12] Turki, N., Harrabi, M. and Okuno, K., 2012. Effect of salinity on grain yield and quality of wheat and genetic relationships among durum and common wheat. $J$. Arid Land Studies, 22(1), pp.311-314.

[13]Zhu, J.K., 2002. Salt and drought stress signal transduction in plants. Annual review of plant biology, 53, p.247. 